Fadi Alfaqs, orcid.org/0000-0003-3427-6454
Faculty of Engineering Technology, Department of Mechanical Engineering, Al-Balqa Applied University, Amman, Jordan, e-mail: faalfaqs@bau.edu.jo

\title{
DYNAMIC ANALYSIS OF THIN LAMINATED VISCOELASTIC STRUCTURES UNDER ELEVATED TEMPERATURE USING FINITE ELEMENT MODELING
}

Purpose. The current study is devoted to investigating the effect of elevated temperature on interlaminar stresses for different laminated viscoelastic structures and boundary conditions. Each structure considered consists of three laminated layers, where the core layer is made of plasticized polyvinyl butyral, which is a viscoelastic material, whereas both constraining layers are made of isotropic structural material silica float glass.

Methodology. Finite element (FE) modeling is used to perform modal, harmonic, and transient analyses. The current viscoelastic composite model is compared to data in literature for verification purposes. Simply supported beam, cantilever, and simply supported plate are studied for temperature variation of $23,40,50$, and $60^{\circ} \mathrm{C}$. Modal analysis is carried out to find natural frequencies for all the structures considered.

Findings. The results obtained show that increasing temperature plays a significant role in reducing the natural frequencies in each structure as well as increasing the transverse deflections and decreasing the corresponding interlaminar shear stresses.

Originality. The literature does not contain a study on the influence of elevated temperatures on interfacial dynamic stresses in laminated viscoelastic structures.

Practical value. One of the main factors affecting the delamination process of composite viscoelastic sandwich structures is the interfacial harmonic shear stresses existing between layers. Hence, harmonic and transient analyses are performed to determine dynamic deflections and interlaminar shear stresses.

Keywords: deflections, beam, dynamics, modeling, shear, vibration, viscoelastic materials

Introduction. Viscoelastic materials are used in various applications such as planes and vehicles to absorb vibration and reduce noise [1]. However, modal analysis is presented theoretically and experimentally by studying free vibration of laminated composite plate where excellent agreement was found [2].

Furthermore, Raleigh-Ritz method analysis was carried out in order to investigate the vibration in viscoelastic laminated cylindrical shell [3] where vibration frequencies were calculated using numerical model to study the boundaries' stiffness impact. Dynamic response of multi-layer thick beams with viscoelastic damping layer was investigated by a number of researchers [4]. Multiple models were developed using Reddy-Bickford shear and Ross-Kerwin-Ungar models since classical failure theory cannot explain testing and experimental results. However, FE Model for a 3-layer composite beam was performed using finite element package ANSYS; two constraining structural layers and a viscoelastic core layer [5]. In addition, both numerical and experimental analyses were compared to validate the FE results.

Other studies used the method of reduction to solve the response of viscoelastic core beams [6]. The results revealed that excellent agreement was observed in addition to reduction of computational cost. On the other hand, Euler-Bernoulli equation was used in finding mode shapes of viscoelastic cantilever sandwich through MATLAB code [7] where results showed good agreement with literature data. Buckling of viscoelastic core plate under elevated thermal environment was investigated analytically [8]. Free vibration analysis was performed to determine the corresponding characteristics.

Investigation of static and dynamic loading for laminates of composite material was performed for failure prediction analysis [9]. The failure criteria predicted in a multi-laminar structure developed lately by Northwestern University were proven by current model. Analysis results showed clearly that generally, the best approach to predict failure in composite laminated structures is yet to be developed.

Detection of carbon fiber laminated composite beam damage was examined experimentally by a group of researchers [10]. It should be said that this experimental vibration analyses were carried out to find natural frequencies and damping

(C) Fadi Alfaqs, 2020 ratio for both laminated and delaminated composite beams where validation with numerical results were obtained using FE package ANSYS. It is eventually concluded that natural frequencies of undamaged beams differ from laminated beams, which results in varying modal analysis. FE analysis was performed to study dynamic behavior of composite laminated plate using different stacking order and boundary conditions [11]. Results revealed that good agreement was obtained with experimental data and data obtained in the literature. Furthermore, location and size of delamination have a significant effect on modal results.

However, failure of fiber reinforced laminated layers was examined using failure approach in continuum mechanics [12]. Moreover, the model which was developed using the approach considered was coded using FE analysis software to validate the results. Furthermore, evaluation of structure failure caused by delamination is performed in this study. A study on dynamic behavior analysis concerning delamination of fiber reinforced composites was carried out using a new method to detect the delamination and hence composites' failure [13]. The results revealed that the size of delamination shows less influence then the position of delamination.

Other researchers performed rotor dynamic analysis simulation to study the effect of gradual failure [14]. Rotor was subjected to out-plane and in-plane load combinations in order to study failure initiation and in-plane damage propagation. The results obtained showed good agreement between experimental and FE dynamic stress results for the rotor considered. However, a model for delamination propagation for FRP composite structures was proposed to monitor failure [15]. The study aims at evaluating interlaminar failure due to delamination using delamination propagation model considered. The new delamination model proposed was coded based on fracture and continuum mechanics where model's results were compiled beside ABAQUS' results.

A review of analytical damage criteria for laminated composite structures was conducted to investigate and estimate the damage criteria capability to predict any failure under static and dynamic loading [16]. Finite element modeling was used to model post-damage phase using implemented intra and interfacial failure criteria.

Dynamic analysis of different viscoelastic structures was carried out using FE package ANSYS by (Al-Huniti, et al., 
2010). As a result, interlaminar shear stresses were investigated since they are responsible for composites' delamination. The results revealed that viscoelastic layer plays a significant role in controlling vibration, and hence, reducing the dynamic deformation of the composite viscoelastic laminated structures. Duser, et al. carried out an analysis of composite plate under uniform static pressure. The simply supported composite plate considered consists of three bonded layers in which the middle layer is a viscoelastic material. Finite element model was developed in order to compare static deflection at the middle of the plate with the literature data. Moreover, analytical model was performed to predict the failure in composite structures under specific boundary conditions

Based on the literature considered above, current work is concerned with studying the influence of elevated surrounding temperature on harmonic and transient interlaminar deflections and shear stresses induced in different viscoelastic sandwich structures where the viscoelastic layer contains no damping. All the structures considered contain a viscoelastic core layer with two structural constraining layers. FE modeling is performed using modal, harmonic, and transient analyses.

Material properties. The structures considered in the current study consist of three laminated layers each; viscoelastic core layer with no damping sandwiched between two isotropic layers. The viscoelastic layer is made of plasticized polyvinyl butyral (PVB) while both constraining layers are made of an isotropic material of silica float glass. It should be said that the elastic modulus of a viscoelastic material is a complex value. The real part represents the elastic characteristics of the material, while the imaginary part represents the viscous properties. These two parts can be presented using a mathematical formula that depends on frequency as shown in Equation (1), (Meunier and Shenoi, 2001).

$$
E_{v}=\dot{E}(1+i \eta)
$$

where $E_{v}$ is the viscoelastic modulus; $\dot{E}$ is the elastic modulus; $\eta$ is the viscosity; $i$ is the imaginary number. However, stress strain data for PVB material was modeled using the official model of Kuraray Europe GMBII. The properties of the isotropic materials used are listed in Table 1.

Finite element models. Finite element models were developed for simply supported, cantilever, and simply supported square plate, as shown in Figs. 1, $a-c$ respectively. Modeling of the structures considered is carried out using ANSYS' software where the type element used to model both silica float glass and PVB layers is an 8-node solid185, while conta174 and Targe 170 are used for contact elements and surfaces respectively. It should be said that modal, harmonic, and transient analyses are performed for all laminated structures considered where convergence is obtained for the finite element solution. Schematic diagram for squared cross section of simply supported and cantilever beams, and simply supported square plate is shown in Fig. 1, $d$ where the depth of simply supported beam and cantilever is $50 \mathrm{~mm}$, while it is $1 \mathrm{~m}$ for the simply supported plate.

However, several assumptions are considered when modeling thin structures (Vinson and Sierakowski, 1986):

Table 1

Properties of composite structures materials

\begin{tabular}{|l|c|c|}
\hline & Silica Float Glass & PVB \\
\hline Density $\left(\mathrm{Kg} / \mathrm{m}^{3}\right)$ & 2500 & 950 \\
\hline Young modulus $(\mathrm{GPa})$ & 72 & 0.05 \\
\hline Poisson's ratio & 0.22 & 0.4 \\
\hline Thermal expansion $\left({ }^{\circ} \mathrm{C}^{-1}\right)$ & $9 \mathrm{E}-6$ & $9 \mathrm{E}-6$ \\
\hline Thermal Conductivity $\left(\mathrm{Wm}^{-1} \mathrm{~K}^{-1}\right)$ & 1 & 0.8 \\
\hline
\end{tabular}


$c$

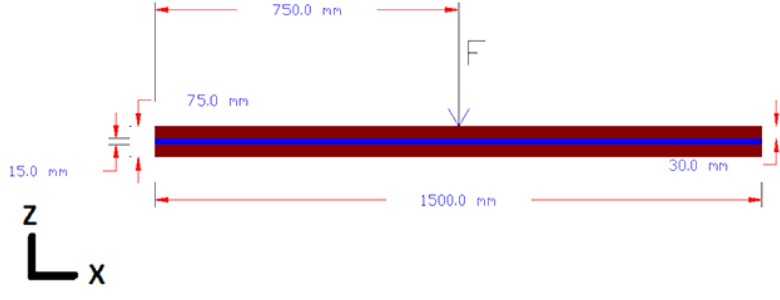

$d$

Fig. 1. Finite element model for viscoelastic laminated structures considered:

$a$ - simply supported beam; $b$ - cantilever; $c$ - simply supported plate; $d$-front view for laminated simply supported beam, cantilever, and simply supported plate

1. Each laminated composite structure consists of perfectly bonded layers.

2. Each layer is a homogenous material with known effective properties.

3. Each layer is in a state of plane stress.

4. The laminate deforms according to the following Kirchoff (Kirchoff-Love) assumptions for bending and stretching of thin plates or beams:

- Normals to the midplane remain straight and normal to the deformed midplane after deformation.

- Normals to the midplane do not change the length.

However, by using the superposition principle of Boltzman, the constitutive equations of thin thermo-viscoelastic structures are shown in Equation (2) [17].

$\left\lfloor\begin{array}{c}\sigma_{x} \\ \sigma_{y} \\ \sigma_{x y}\end{array}\right\rfloor=\frac{1}{1-v^{2}}\left[\begin{array}{ccc}E_{v} & v E_{v} & 0 \\ v E_{v} & E_{v} & 0 \\ 0 & 0 & \frac{(1-v)}{2} E_{v}\end{array}\right\rfloor\left[\begin{array}{c}\epsilon_{x} \\ \epsilon_{y} \\ \gamma_{x y}\end{array}\right]-\frac{E_{v}}{1-v}\left[\begin{array}{c}\alpha \Delta T \\ \alpha \Delta T \\ 0\end{array}\right]$,

where $\mathrm{v}$ is Poisson's ratios, $\left[\begin{array}{c}\sigma_{x} \\ \sigma_{y} \\ \sigma_{x y}\end{array}\right\rfloor$ and $\left[\begin{array}{c}\epsilon_{x} \\ \epsilon_{y} \\ \gamma_{x y}\end{array}\right]$ represent thermo viscoelastic stress and strain of the thin narrow strip respectively; $\alpha$ is a linear expansion coefficient; $\Delta T$ is the net rise of temperature of the thin narrow strip. 
Furthermore, the equation of motion which finite element package uses in order to determine the displacements with thermal condition presence at every node is presented in Equation (3).

$$
\begin{aligned}
& {\left[\begin{array}{cc}
{[M]} & {[0]} \\
\lfloor 0\rfloor & \lfloor 0\rfloor
\end{array}\right]\left\{\begin{array}{l}
\ddot{u} \\
\ddot{T}
\end{array}\right\}+\left[\begin{array}{cc}
{[C]} & {[0]} \\
\left\lfloor C^{t u}\right\rfloor & \left\lfloor C^{t}\right]
\end{array}\right]\left\{\begin{array}{c}
\dot{u} \\
\dot{T}
\end{array}\right\}+} \\
& +\left[\begin{array}{c}
{[K]\left[K^{u t}\right]} \\
\lfloor 0\rfloor\left[K^{t}\right]
\end{array}\right]\left\{\begin{array}{l}
u \\
T
\end{array}\right\}=\left\{\begin{array}{l}
\{F\} \\
\{Q\}
\end{array}\right\},
\end{aligned}
$$

where $[M]=$ element mass matrix; $[C]=$ element structural damping matrix; $[K]=$ element stiffness matrix; $\{u\}=$ displacement vector; $\{F\}=$ sum of the element nodal force; $\left[C^{t}\right]=$ element specific heat matrix; $\left[K^{t}\right]=$ element thermal conductivity matrix; $\{T\}=$ temperature vector; $\{Q\}=$ sum of the element heat generation load and element convection surface heat flow vectors; $\left[C^{t u}\right]=$ element thermoelastic damping matrix $=-T_{0}\left[K^{u t}\right]^{T}$; $[B]=$ strain-displacement matrix; $\{N\}=$ element shape functions; $\left[K^{u t}\right]$ is the element thermoelastis stiffness matrix $=$ $=-\int_{\text {vol }}\left[B^{T}\right]\{\beta\}\left\{N^{T}\right\} d(\mathrm{vol}) ; T_{o}$ is the reference temperature

Model verification. Finite element viscoelastic laminated structure model verification was performed in order to validate current work. Experimental results for simply supported viscoelastic sandwich plate subjected to uniform pressure obtained by (Duser, et al., 1999) were compared with current finite element results in ANSYS where good agreement was found as shown in Fig. 2. The composite plate considered consists of three layers; two constraining layers are made of silica float glass whereas the interlayer is made of plasticized polyvinyl butyral (PVB). The applied pressure varied from 1000 to $7000 \mathrm{~Pa}$.

Results. Modal analyses are performed on all composite structures considered (simply supported, cantilever, simply supported plate) for various temperature values $23,40,50$, and $60{ }^{\circ} \mathrm{C}$ to investigate the corresponding natural frequencies. The first five natural frequencies which lie within $0-600 \mathrm{~Hz}$ are listed and compared in Tables 2-4 for all the viscoelastic sandwich structures modeled and the temperature variation considered above, where the room temperature is considered $23^{\circ} \mathrm{C}$. It is clearly observed that when the temperature increases, all mode frequencies decrease for each structure. This is reasonable, since elevated temperatures will definitely increase the structure temperature which weakens the interatomic bonding in solid materials and hence weakening material's stiffness and strength, which in turn affects the natural frequencies inversely.

Table 2 illustrates the first five natural frequencies of a laminated simply supported beam for temperature magnitudes of 23 (room temperature), 40,50 , and $60^{\circ} \mathrm{C}$. It can be clearly seen that the maximum fundamental frequency $94.354 \mathrm{~Hz}$ is obtained at room temperature for the beam considered whereas the minimum fundamental frequency of $22.566 \mathrm{~Hz}$ is recorded at $60{ }^{\circ} \mathrm{C}$.

Finite element harmonic analyses were carried out for the thin laminated simply supported beam where a force of magnitude of $1000 \mathrm{~N}$ is applied at the mid of the beam for driving frequency range $0-500 \mathrm{~Hz}(0-3140 \mathrm{rad} / \mathrm{s})$. Maximum transverse

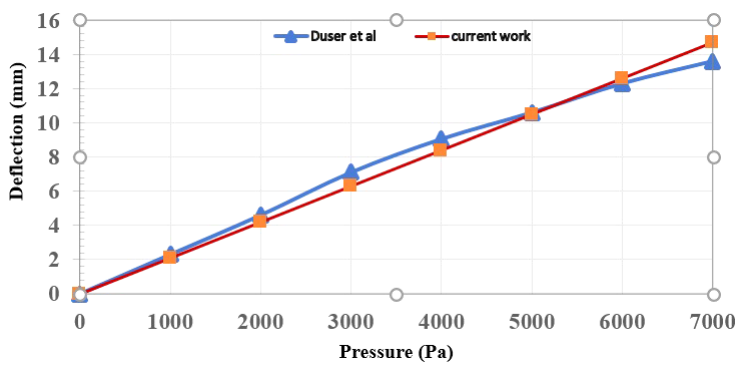

Fig. 2. Comparison between current finite element model results and (Duser, et al., 1999) deflections and interlaminar shear stresses were studied for temperature variation $40-60{ }^{\circ} \mathrm{C}$ as seen in Fig. 3, $a$ and Fig. 3, $b$ respectively. Generally, increasing the temperature values increases the transverse deflection and decreases shear stress along the simply supported beam where maximum values of deflections and interlaminar shear stresses are achieved at the mid-point and the support respectively. Maximum deflection is found to be $2.39 \mathrm{~mm}$ at $37 \mathrm{~Hz}$ when temperature of $60{ }^{\circ} \mathrm{C}$ is applied. However, maximum shear stress was recorded as $0.058 \mathrm{MPa}$ at 400 $\mathrm{Hz}$ in a room temperature environment $\left(23^{\circ} \mathrm{C}\right)$. Furthermore, the second largest value of deflection is recorded as $1.45 \mathrm{~mm}$ at a frequency of $50 \mathrm{~Hz}$ and a temperature of $50{ }^{\circ} \mathrm{C}$ whereas the second highest value of interlaminar shear stress is found to be $0.054 \mathrm{MPa}$ at a frequency and temperature of $170 \mathrm{~Hz}$ and $23^{\circ} \mathrm{C}$ respectively. The effect of natural frequencies on both maximum deflection and shear stress is clearly observed where values highly jump as the driving frequency nearly matches the natural values of frequency since the viscoelastic material is frequency dependent. However, it should be said that interlaminar shear stresses induced during harmonic analysis at a temperature of $23{ }^{\circ} \mathrm{C}$ have larger values for all frequency range compared to stresses resulted at other temperature values since shear stress is inversely proportional to temperature (Andrei, et al., 2006).

The relation between harmonic response of deflection and interlaminar shear stress versus driving frequency are presented in Figs. 5, $a, b$ respectively for viscoelastic sandwich cantilever.

Table 2

First five natural frequencies of laminated simply supported viscoelastic sandwich beam for different temperatures

\begin{tabular}{|c|c|c|c|c|c|}
\hline \multicolumn{7}{|c|}{ Natural Frequencies } \\
\hline $\begin{array}{c}\text { Temperature } \\
\left({ }^{\circ} \mathrm{C}\right)\end{array}$ & $\begin{array}{c}\text { First } \\
\text { Mode }\end{array}$ & $\begin{array}{c}\text { Second } \\
\text { Mode }\end{array}$ & $\begin{array}{c}\text { Third } \\
\text { Mode }\end{array}$ & $\begin{array}{c}\text { Fourth } \\
\text { Mode }\end{array}$ & $\begin{array}{c}\text { Fifth } \\
\text { Mode }\end{array}$ \\
\hline 23 & 94.354 & 145.23 & 272.26 & 403.37 & 510.10 \\
\hline 40 & 47.737 & 115.05 & 171.66 & 194.26 & 206.60 \\
\hline 50 & 45.752 & 92.347 & 127.64 & 131.80 & 156.94 \\
\hline 60 & 22.566 & 27.314 & 29.081 & 36.981 & 66.820 \\
\hline
\end{tabular}

Table 3

First five natural frequencies of laminated viscoelastic sandwich cantilever for different temperatures

\begin{tabular}{|c|c|c|c|c|c|}
\hline \multicolumn{7}{|c|}{ Natural Frequencies } \\
\hline $\begin{array}{c}\text { Temperature } \\
\left({ }^{\circ} \mathrm{C}\right)\end{array}$ & $\begin{array}{c}\text { First } \\
\text { Mode }\end{array}$ & $\begin{array}{c}\text { Second } \\
\text { Mode }\end{array}$ & $\begin{array}{c}\text { Third } \\
\text { Mode }\end{array}$ & $\begin{array}{c}\text { Fourth } \\
\text { Mode }\end{array}$ & $\begin{array}{c}\text { Fifth } \\
\text { Mode }\end{array}$ \\
\hline 23 & 39.675 & 41.758 & 174.24 & 258.84 & 400.69 \\
\hline 40 & 19.073 & 41.742 & 107.55 & 258.42 & 264.12 \\
\hline 50 & 17.761 & 41.740 & 105.87 & 186.00 & 257.94 \\
\hline 60 & 16.800 & 41.692 & 63.674 & 95.961 & 104.58 \\
\hline
\end{tabular}

Table 4

First five natural frequencies of laminated simply supported viscoelastic sandwich plate for different temperatures

\begin{tabular}{|c|c|c|c|c|c|}
\hline \multicolumn{7}{|c|}{ Natural Frequencies } \\
\hline $\begin{array}{c}\text { Temperature } \\
\left({ }^{\circ} \mathrm{C}\right)\end{array}$ & $\begin{array}{c}\text { First } \\
\text { Mode }\end{array}$ & $\begin{array}{c}\text { Second } \\
\text { Mode }\end{array}$ & $\begin{array}{c}\text { Third } \\
\text { Mode }\end{array}$ & $\begin{array}{c}\text { Fourth } \\
\text { Mode }\end{array}$ & $\begin{array}{c}\text { Fifth } \\
\text { Mode }\end{array}$ \\
\hline 23 & 196.47 & 351.30 & 351.30 & 518.66 & 605.21 \\
\hline 40 & 118.52 & 235.93 & 235.94 & 240.48 & 243.19 \\
\hline 50 & 115.39 & 185.10 & 185.10 & 185.54 & 227.82 \\
\hline 60 & 94.615 & 94.616 & 94.732 & 105.58 & 169.35 \\
\hline
\end{tabular}


It is clearly seen that as the temperature increases, the deflection rises and the shear stress drops. Furthermore, when driving frequency reaches about $20 \mathrm{~Hz}$, which represents a fundamental frequency for all the cases considered, transverse deflections and interlaminar shear stresses for the temperature variation record high values as the driving frequency equals the respective natural frequencies. Maximum deflection of

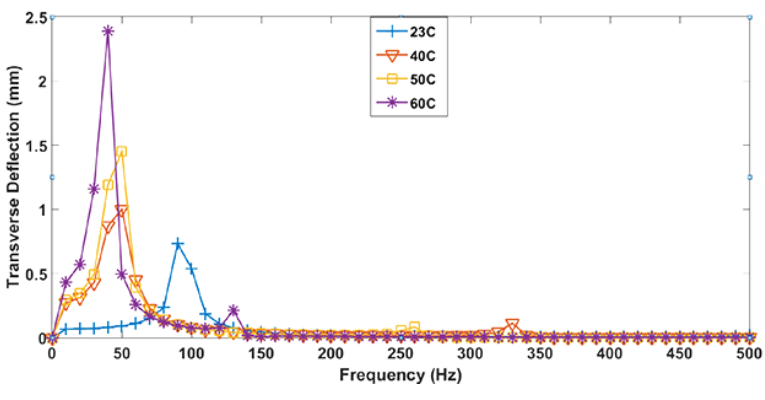

$a$

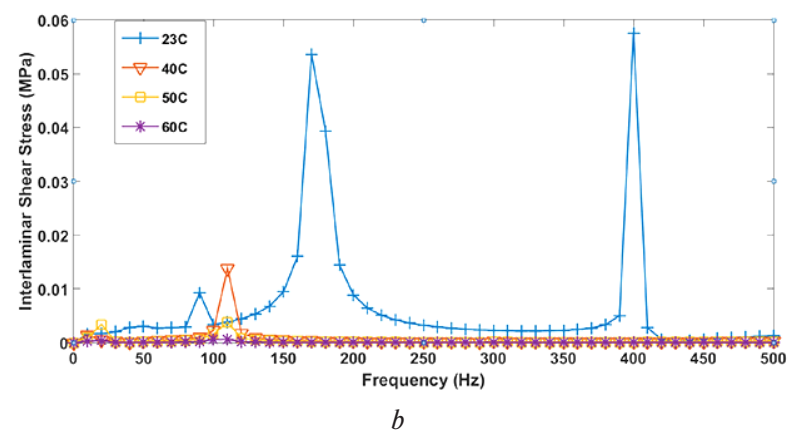

Fig. 3. Harmonic response of viscoelastic core sandwich simply supported beam versus driving frequency for different temperatures:

$a$ - Variation of transverse deflection; $b$ - Variation of interlaminar shear stress

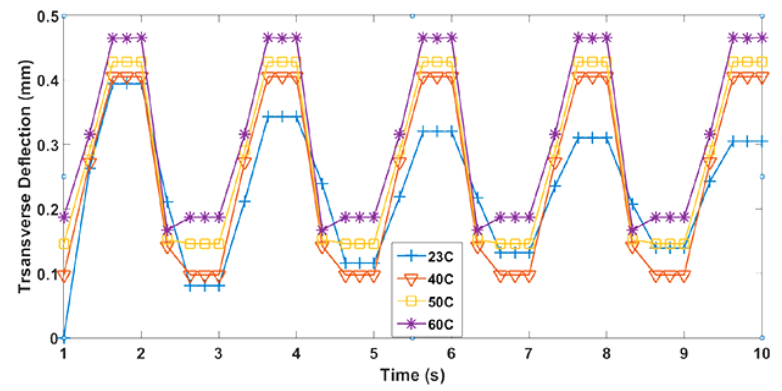

$a$

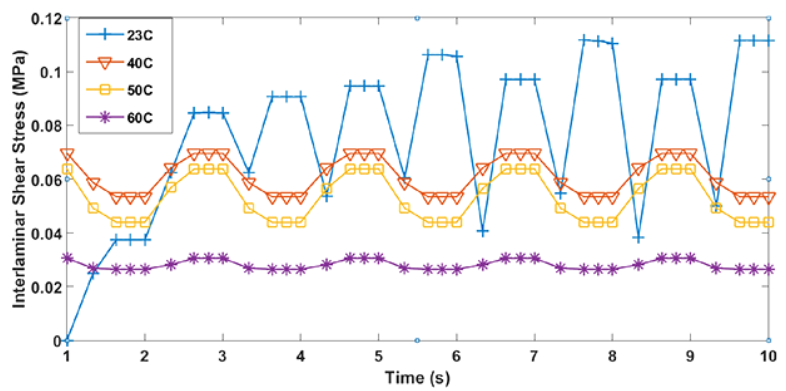

$b$

Fig. 4. Transient response of viscoelastic core sandwich simply supported beam versus driving frequency for different temperatures:

$a$ - Variation of transverse deflection; $b$ - Variation of interlaminar shear stress
$8.45 \mathrm{~mm}$ is obtained at a temperature of $60{ }^{\circ} \mathrm{C}$ whereas maximum shear stress is found to be $12.6 \mathrm{MPa}$ at room temperature.

Influence of the temperature on transverse deflection and interfacial shear stress of viscoelastic sandwich cantilever is investigated for frequency range $0-500 \mathrm{~Hz}$ as shown in Fig. 6, $a$ and Fig. $6, b$ respectively where alternating response is observed at both relations. Moreover, Figures indicate that when
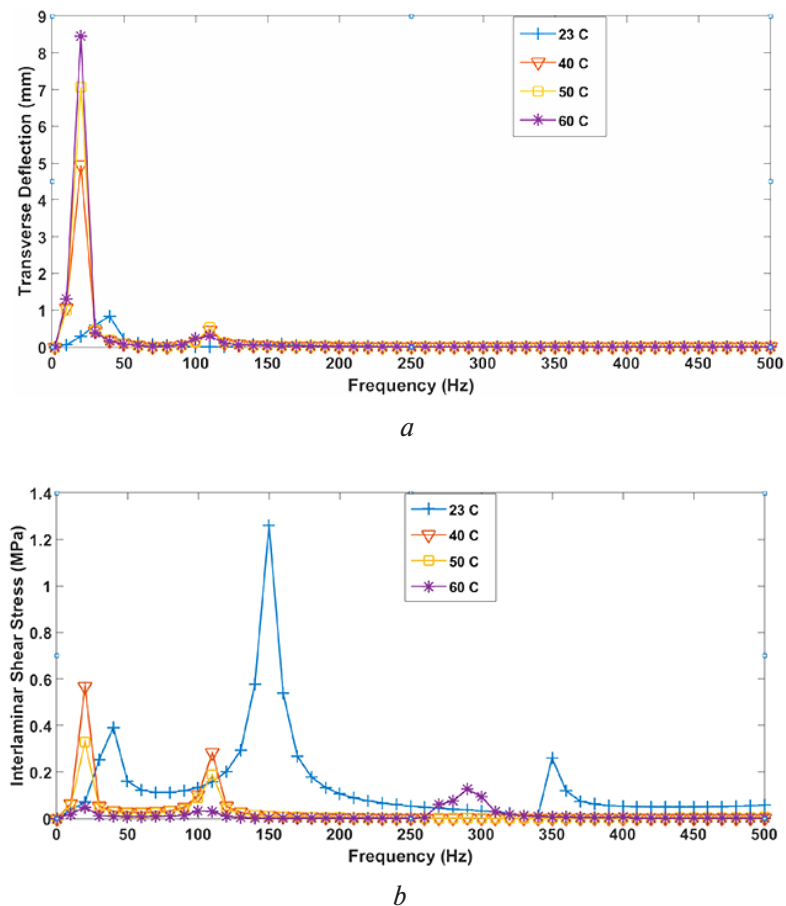

Fig. 5. Harmonic response of viscoelastic core sandwich cantilever versus driving frequency for different temperatures:

$a$ - Variation of transverse deflection; $b$ - Variation of interlaminar shear stress
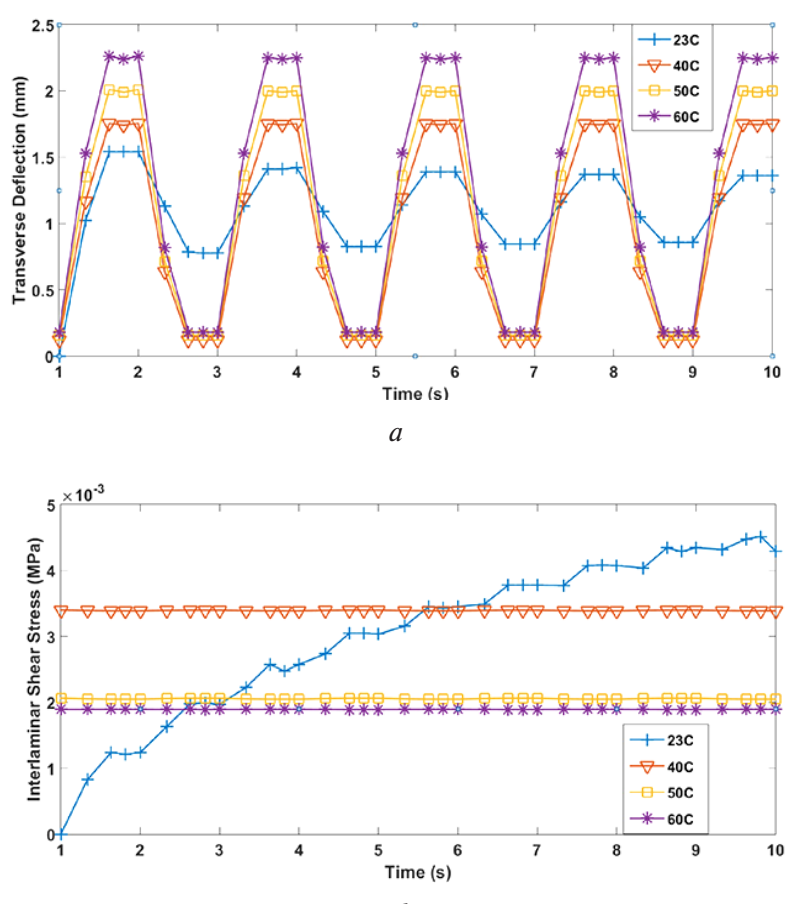

Fig. 6. Transient response of viscoelastic core sandwich cantilever versus driving frequency for different temperatures.

$a$-Variation of transverse deflection; $b$ - Variation of interlaminar shear stress 
increasing the temperature, deflection values increase accordingly while on the other hand, shear stresses are inversely proportional to temperature variation. It should be said that at room temperature and at the early stages, interlaminar shear stress records small values. However, and due to no damping effect, stresses rise sharply. Furthermore, it is observed that the variation of shear stress at temperatures of 40,50 , and $60{ }^{\circ} \mathrm{C}$ are limited compared to the room temperature case.

Figs. 7, $a, b$ present harmonic deflections and interlaminar stresses of a simply supported square plate for a frequency variation of $0-500 \mathrm{~Hz}$. A $1000-\mathrm{N}$ force is applied in the middle of the plate to investigate the harmonic response of the plate considered. It is clearly seen that similar trend is observed as in beam cases, that is, increasing the environment temperature leads to transverse deflection increase and shear stress decrease. It can be concluded that maximum harmonic deflection of $0.391 \mathrm{~mm}$ is recorded at about $110 \mathrm{~Hz}$, while a maximum shear stress of $0.0142 \mathrm{MPa}$ is obtained at $200 \mathrm{~Hz}$ for the $40{ }^{\circ} \mathrm{C}$ case in the frequency range considered.

Transient transverse deflection and interlaminar shear stresses are studied under a $1000 \mathrm{~N}$ impact force concentrated in the middle of the plate for a time range $1-10 \mathrm{~s}$ as depicted in Figs. 8, $a$ and $8, b$ respectively. It is observed that as temperature increases, transient deflection increases and interlaminar transient shear stress decreases. It should be said that the highest value of deflection and shear stress induced are $0.3 \mathrm{~mm}$ at $60{ }^{\circ} \mathrm{C}$ and $0.0204 \mathrm{MPa}$ at $23{ }^{\circ} \mathrm{C}$ respectively.

Conclusions. Modal, harmonic, and transient analyses are performed using finite element models which are developed using the student version of Ansys. Deflections and interfacial stresses are obtained for both temperature and frequency variations. Modal analyses results revealed that increasing the temperature leads to natural frequency decrease for each case considered. However, applying harmonic excitation provided an increase in the transverse deflection while reducing the interlaminar shear stresses. This indicates that while increasing the temperature, interlaminar shear stress will no longer play a significant role in layers delamination since lower values are obtained.

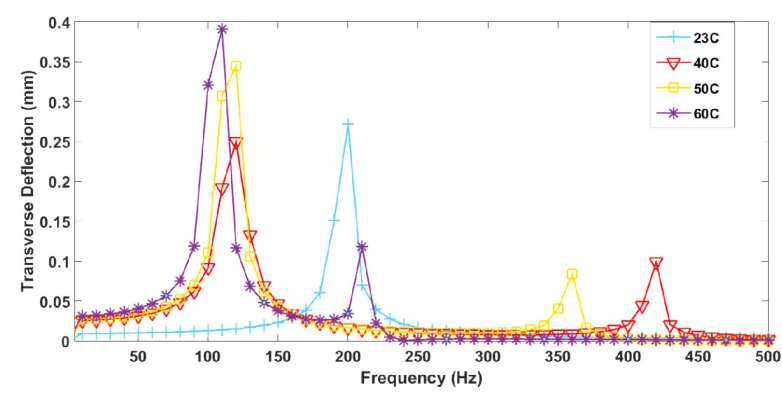

$a$

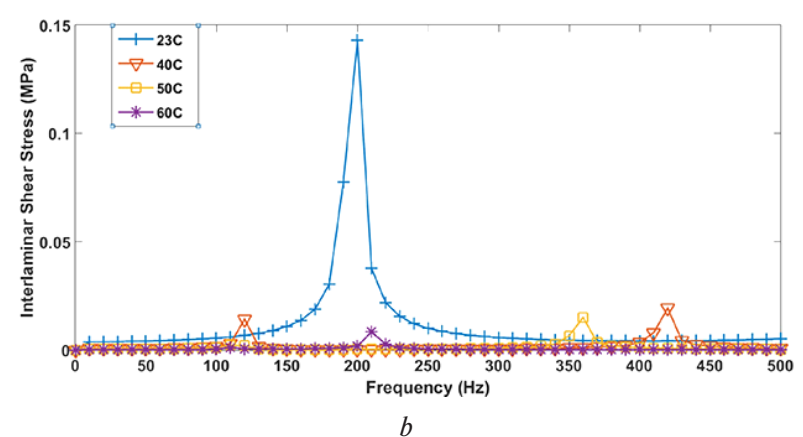

Fig. 7. Harmonic response of viscoelastic core sandwich simply supported plate versus driving frequency for different temperatures:

$a$ - Variation of transverse deflection; $b$ - Variation of interlaminar shear stress
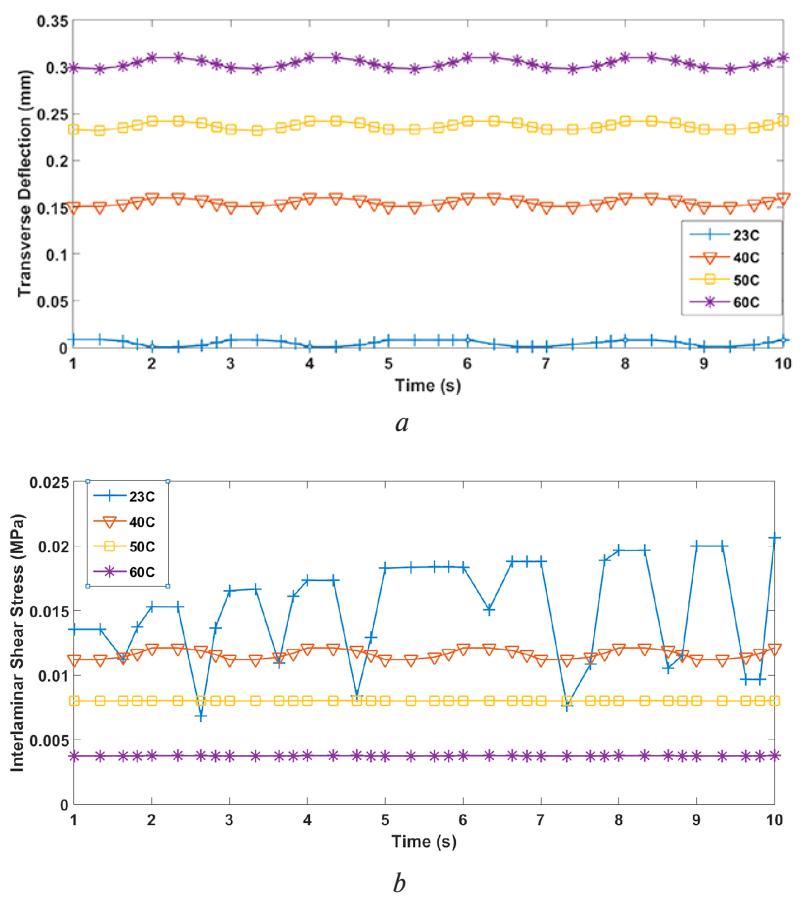

Fig. 8. Transient response of viscoelastic core sandwich simply supported plate versus driving frequency for different temperatures:

$a$ - Variation of transverse deflection; $b$ - Variation of interlaminar shear stress

However, when driving frequency equals the natural frequency, high deflection results occur due to resonance phenomenon. Hence, if any failure occurs, it is due to driving frequency value where natural frequency has a significant effect on both transverse deflection and interlaminar shear stress so that high values are recorded. Furthermore, transient analysis results provided the same trend of harmonic results but produced an alternating response where the no-damping effect resulted eventually in large values of interlaminar shear stress at a room temperature.

\section{References.}

1. Fotsing, E., Sola, M., Ross, A., \& Ruiz, E. (2013). Dynamic characterization of viscoelastic materials used in composite structures. Journal of Composite Materials, 48(30), 38153825. https://doi.org/10.1177/0021998313514254.

2. Zhao, L., \& Wu, J. (2013). Natural frequency and vibration modal analysis of composite laminated plate. In: Advanced Materials Research, (2013), (pp. 396-400). https://doi. org/10.4028/www.scientific.net/AMR.711.396.

3. Song, X., Cao, T., Gao, P., \& Han, Q. (2020). Vibration and damping analysis of cylindrical shell treated with viscoelastic damping materials under elastic boundary conditions via a unified Rayleigh-Ritz method. International Journal of Mechanical Sciences, 165, 1-17. https://doi. org/10.1016/j.ijmecsci.2019.105158.

4. Cortés, F., \& Sarría, I. (2015). Dynamic Analysis of ThreeLayer Sandwich Beams with Thick Viscoelastic Damping Core for Finite Element Applications. Shock and Vibration, 2015, 1-9. https://doi.org/10.1155/2015/736256.

5. Huang, Z., Wang, X., Wu, N., Chu, F., \& Luo, J. (2019). A finite element model for the vibration analysis of sandwich beam with frequency-dependent viscoelastic material core. Materials, 12(20), 1-15.https://doi.org/10.3390/ma12203390. 6. Boumediene, F., Daya, E. M., Cadou, J.-M., \& Duigou, L. (2016). Forced harmonic response of viscoelastic sandwich beams by a reduction method. Mechanics of Advanced Materials and Structures, 23(11), 1290-1299. https://doi.org/1 $\underline{0.1080 / 15376494.2015 .1068408}$. 
7. Rajesh, C., \& Suresh Kumar, J. (2016). Free Vibration Analysis of Viscoelastic Sandwich Beam using Euler Bernoulli Theory. International Journal of Engineering Research \& Technology (IJERT), 5(06). https://doi.org/10.17577/IJERTV5IS060739. 8. Joseph, S. V., \& Mohanty, S. C. (2017). Temperature effects on buckling and vibration characteristics of sandwich plate with viscoelastic core and functionally graded material constraining layer. Journal of Sandwich Structures and Materials, 21(4), 1557-1577. https://doi.org/10.1177/1099636217722309. 9. Daniel, I. M. (2014). Failure of composite materials under multi-axial static and dynamic loading. In: Procedia Engineering. (2014), (pp. 10-17).https://doi.org/10.1016/j.proeng.2014.11.120. 10. Sadarang, J., Nayak, S., Nayak, G., Panigrahi, I., \& Nayak, R. K. (2018). Dynamic analysis for delamination detection in carbon fiber composite beam. In: IOP Conference Series: Materials Science and Engineering, (2018), (pp. 1-6). https:// doi.org/10.1088/1757-899X/402/1/012143.

11. Naveen Raj, C., Praveen, N., \& Sandeep Kumar, J. (2016). Dynamic Analysis of Composite Plate using Finite Element Analysis. International Journal of Engineering Research \& Technology, 5(11), 270-282. ISSN: 2278-0181.

12. Shojaei, A., Li, G., Tan, P. J., \& Fish, J. (2015). Dynamic delamination in laminated fiber reinforced composites: A continuum damage mechanics approach. International Journal of Solids and Structures, 71, 262-276. https://doi.org/10.1016/j. ijsolstr.2015.06.029.

13. Shen, Y., Tan, J., Fernandes, L., Qu, Z., \& Li, Y. (2019). Dynamic mechanical analysis on delaminated flax fiber reinforced composites. Materials, 12(16). https://doi.org/10.3390/ ma12162559.

14. Filippatos, A., Langkamp, A., \& Gude, M. (2018). Influence of gradual damage on the structural dynamic behaviour of composite rotors: Simulation assessment. Materials, 11(12). https://doi.org/10.3390/ma11122453.

15. Aveiga, D., \& Ribeiro, M.L. (2018). A Delamination Propagation Model for Fiber Reinforced Laminated Composite Materials. Mathematical Problems in Engineering, 2018, 1-9. https://doi.org/10.1155/2018/1861268.

16. Luca, A.De., \& Caputo, F. (2017). A review on analytical failure criteria for composite materials. AIMS Materials Science, 4(5), 1165-1185. https://doi.org/10.3934/matersci.2017.5.1165. 17. Qi, L., \& Liu, H. (2015). Thermoviscoelastic dynamic response for a composite material thin narrow strip. Journal of Mechanical Science and Technology, 31(1), 625-635. https:// doi.org/10.1007/s12206-015-0122-1.

\section{Динамічний аналіз тонкошарових в'язкопружних конструкщій при підвищеній температурі з використанням моделювання методом скінченних елементів}

\section{Фаді Альфакс}

Кафедра машинобудування, факультет інженерних технологій, Аль-Балка прикладний університет, м. Амман, Йорданія, e-mail: faalfaqs@bau.edu.jo

Мета. Це дослідження присвячене вивченню впливу підвищеної температури на міжшарові напруги для різних композитних сендвіч-структур і граничних умов. Кожна конструкція складається із трьох ламінованих шарів, де центральний шар виконаний із пластифікованого полівінілбутираля, що є в'язкопружним матеріалом. Два інших обмежуючих шари виконані з ізотропного структурного матеріалу - кремнієвого флоат-скла.

Методика. Моделювання методом кінцевих елементів застосовано для проведення модального, гармонійного й перехідного аналізів. Поточна модель в'язкопружного сендвіча порівнюється з даними в літературних джерелах. Вільно обперта балка, консольна балка й вільно обперта пластина вивчаються за зміни температур 23, 40, 50 і
$60{ }^{\circ} \mathrm{C}$. Аналізом методу нормальних хвиль виконано визначення власних частот і форм коливань для всіх розглянутих структур.

Результати. Отримані результати показують, що підвищення температури грає важливу роль у зменшенні власних частот у кожній структурі, а також у збільшенні поперечних прогинів і зменшенні відповідних міжшарових зсувних напружень.

Наукова новизна. Література не містить дослідження впливу підвищених температур на міжшарові динамічні напруги у в'язкопружних сендвіч-структурах.

Практична значимість. Одним з основних факторів, що впливають на процес розшаровування композитних в'язкопружних багатошарових структур, є міжфазні гармонійні напруги зсуву між шарами. Отже, гармонійний аналіз і аналіз перехідних процесів виконані для визначення динамічних відхилень і міжшарових напружень зсуву.

Ключові слова: прогини, балка, динаміка, моделювання, зріз, вібрація, в'язкопружні матеріали

\section{Динамический анализ тонкослоистых \\ вязкоупругих структур при повышенной температуре с использованием моделирования методом конечных элементов}

Фади Альфакс

Кафедра машиностроения, факультет инженерных технологий, Аль-Балка прикладной университет, г. Амман, Иордания, e-mail: faalfaqs@bau.edu.jo

Цель. Настоящее исследование посвящено изучению влияния повышенной температуры на межслойные напряжения для различных композитных сэндвич-структур и граничных условий. Каждая конструкция состоит из трёх ламинированных слоёв, где центральный слой выполнен из пластифицированного поливинилбутираля, который является вязкоупругим материалом. Два других ограничивающих слоя выполнены из изотропного структурного материала - кремниевого флоат-стекла.

Методика. Моделирование методом конечных элементов применено для проведения модального, гармонического и переходного анализов. Текущая модель вязкоупругого сэндвича сравнивается с данными в литературных источниках. Свободно опертая балка, консольная балка и свободно опертая пластина изучаются при изменении температур $23,40,50$ и $60{ }^{\circ} \mathrm{C}$. Анализом метода нормальных волн выполнено определение собственных частот и форм колебаний для всех рассматриваемых структур.

Результаты. Полученные результаты показывают, что повышение температуры играет важную роль в уменьшении собственных частот в каждой структуре, а также в увеличении поперечных прогибов и уменьшении соответствующих межслойных сдвиговых напряжений.

Научная новизна. Литература не содержит исследования влияния повышенных температур на межслойные динамические напряжения в вязкоупругих сэндвич-структурах.

Практическая значимость. Одним из основных факторов, влияющих на процесс расслаивания композитных вязкоупругих многослойных структур, являются межфазные гармонические напряжения сдвига между слоями. Следовательно, гармонический анализ и анализ переходных процессов выполнены для определения динамических отклонений и межслойных напряжений сдвига.

Ключевые слова: прогибы, балка, динамика, моделирование, срез, вибрация, вязкоупругие материаль

Recommended for publication by Mamdoh Abd Alaziz AIBusoul, Professor of Mechanical Engineering. The manuscript was submitted 01.05.20. 